\title{
Suomen nykynuorten käsityksiä Karjalasta
}

Tämä artikkeli käsittelee ennen tutkimatonta aihetta: Minkälaisia merkityksiä Suomessa asuvat nykynuoret liittävät Karjalaan? Kysymykseen vastataan fokusryhmähaastatteluilla vuonna 2017 kerätyn aineiston avulla. Tutkimuksessa haastateltiin lukiolaisia (16-19 vuotta) ympäri Suomen. Tässä artikkelissa "Karjala" viittaa maantieteelliseen Karjalaan, jonka Suomi luovutti Neuvostoliitolle toisen maailmansodan seurauksena. Aiemmat tutkimukset ovat osoittaneet, että monet Karjalan jättäneistä suomalaisista pitävät sitä "täydellisenä menetettynä paikkana". Tulokset osoittavat, että Karjalalla on nuorten elämässä merkitystä, se on heille läsnä, ja he tuntevat olevansa osa "meitä", jotka menettivät Karjalan.

Chloe Wells

Tässä artikkelissa tutkin sitä, miten nuoret ilmaisevat Suomelle ennen kuuluneeseen alueeseen, Karjalaan, liittyviä merkityksiä. "Nuorilla” tarkoitan nuoria ihmisiä, jotka asuvat ja käyvät lukiota Suomessa riippumatta siitä, onko heillä suomalaisen tai muunmaalaisen identiteetti. Nykynuorissa on useampi sukupolvi sellaisia, joilla on henkilökohtaisia muistoja elämästä luovutetulla alueella. Artikkelin tavoitteena on etsiä vastauksia päätutkimuskysymykseen: Mitä merkityksiä Suomen nykynuoret liittävät "Karjalaan"? Lisäksi pyrin vastaamaan seuraaviin kysymyksiin: Miten "tilallinen sosialisaatio" (eng. spatial socialisation, Paasi 1996; 2016) ja (arkipäivän) nationalismi (Billig 1995) vaikuttavat nuorten antamiin merkityksiin? Ovatko nuorten Karjalaan yhdistämät merkitykset samanlaisia vai erilaisia verrattuna luovutetulta alueelta evakuoitujen suomalaisten ilmaisemiin ja suomalaisessa mediadiskurssissa esiintyviin merkityksiin? Tämän tutkimuksen keskiössä ovat nuoret ja heidän tietämyksensä, 
ajatuksensa ja näkökulmansa. Tarkemmin sanottuna artikkeli pyrkii ymmärtämään, miten nuoret mielsivät Karjalan ja miten he kuvasivat sitä tutkijan johtamissa fokusryhmissä. Tilallinen sosialisaatio tarkoittaa prosesseja, joiden kautta kansallisvaltion asukkaat sosiaalistuvat tiettyihin kansallisiin ja alueellisiin käsityksiin (Paasi 1996; 2016 ja alla). Käsite toimii artikkelin analyyttisena työkaluna ja sen avulla voidaan kontekstualisoida ja ymmärtää tutkimukseen osallistuneiden vastauksia.

Tutkimuksen kohteena olevat Suomessa asuvat nuoret ymmärretään tutkimuksessa kolmanneksi sukupolveksi johtuen heidän suhteestaan luovutetun Karjalan muistoihin. Ensimmäiseen sukupolveen kuuluvat ne, joilla on henkilökohtaisia muistoja luovutetusta Karjalasta, toiseen sukupolveen kuuluvat heidän lapsensa ja muut toisen maailmansodan jälkeen syntyneet suomalaiset ja kolmanteen sukupolveen kuuluvat täysi-ikäisyyden kynnyksellä olevat nykynuoret Suomessa. Välittyneiden historiallisten muistojen merkittävyyttä suomalaisten nuorten arjessa on tutkittu aiemmin vain vähän (Wolnik et al. 2016, 5). Tämän tutkimuksen tavoitteena oli saada aiheesta lisätietoa ja tutkia, mitä Karjala merkitsee ja edustaa nykynuorille Suomessa. Viimeaikainen nuorisotutkimus ei pidä nuoria passiivisina kansoja ja alueita koskevien diskurssien vastaanottajina, vaan aktiivisina toimijoina, jotka ovat mukana vaikuttamassa ja rakentamassa näitä diskursseja (ks. esim. Habashi 2014). Tämä artikkeli pyrkii täydentämään olemassa olevaa tutkimusta tarkastelemalla, miten suomalaiset nuoret muodostavat merkityksiä Karjalasta, joka esitetään suomalaisessa diskurssissa usein idealisoituna ja myyttisenä kansallisesta alueesta menetettynä osana (Laine \& van der Velde 2017). Artikkelin pyrkimyksenä on ottaa huomioon nuorten aktiivinen rooli suhteessa Karjalaan sen sijaan, että heitä pidettäisiin tilallisen sosialisaation passiivisina objekteina. Nuoriin keskittymällä tämä artikkeli pyrkii myös avartamaan Karjalaan liittyviä käsityksiä. Tieteellinen keskustelu on keskittynyt pääasiassa evakuoitujen suomalaisten Karjalaan liittämiin merkityksiin ja muistoihin. Tämä artikkeli nostaa esiin Suomessa elävien nykynuorten äänen.

\section{Karjala historiallisessa viitekehyksessä ja muistojen Karjalasta}

Karjala on nykypäivänä Suomen ja Venäjän valtioiden välisen rajan molemmille puolille levittäytyvä raja-alue. Se on alue, joka on ollut ja on yhä keskeinen niille myyteille ja kansallis-alueellisille käsityksille, jotka luovat (yhä uudelleen) mielikuvaa Suomesta erillisenä kansallisvaltiona (Laine \& van der Velde 2017). Tässä artikkelissa Karjala viittaa maantieteelliseen alueeseen, josta tuli osa Neuvostoliittoa (ja sittemmin Venäjää), kun Suomen ja Venäjän välistä rajaa siirrettiin länteen päin toisen maailmansodan jälkeen. Tämä on se merkitys, jonka suomalaiset yleensä liittävät käsitteeseen Karjala (Browning \& Joenniemi 2014, 2; ks. myös Jukarainen 2003, 231).

Sodista ja rauhansopimuksista johtuen Karjalan läpi kulkeva raja on siirtynyt lukuisia kertoja historian saatossa (ks. Liikanen 2014). Viimeisimmät rajamuutokset ratifioitiin vuonna 1947, kun Suomi luovutti noin 10 prosenttia maa-alueestaan Neuvostoliitolle. Suurin osa luovutetusta alueesta oli Karjalassa. Toisen maailmansodan aikana suomalaiset evakuoitiin Karjalasta kahdesti: ensin vuosina 1939-1940 ja toisen kerran vuonna 1944. Vuosina 1941-1944 Suomi valtasi Karjalan takaisin, ja noin 70 \% evakoista muutti takaisin alueelle (Savolainen 2017, 171). Toisen maailmansodan aikana ja sen jälkeen noin 407000 ihmistä eli 10 \% Suomen sodanaikaisesta väestöstä siirrettiin Karjalasta nykyisen Suomen alueelle, joten ei ole poikkeuksellista, että tämän päivän suomalaisella on sukujuuria luovutetussa Karjalassa ja sitä kautta yhteys alueeseen. Se osa Karjalaa, joka Suomen oli luovutettava toisen 
maailmansodan jälkeen, on nykyisin osa Leningradin hallintoaluetta ja Karjalan tasavaltaa tai suomalaisen käsityksen mukaan osa Karjalankannasta ja Raja-Karjalaa/Laatokan Karjalaa. Toisen maailmansodan jälkeisen rajasiirron myötä Suomeen luotiin kaksi uutta hallinnollista aluetta: Pohjois-Karjala ja Etelä-Karjala (ks. Katajala \& Liikanen 2018).

Toisen maailmansodan jälkeen Suomen oli turvattava hyvät välit Neuvostoliittoon. Tämä oli ulkopoliittista tasapainoilua, mikä johti suomettumisen käsitteen syntymiseen. Käsite syntyi kuvaamaan tilannetta, jossa vahvalla naapurivaltiolla oli suuri vaikutus itsenäisen valtion poliittisiin näkemyksiin. Samalla välteltiin niin kutsuttua Karjala-kysymystä eli Karjalan Suomelle palauttamista käsittelevää virallista keskustelua. Neuvostoliiton hajoamisen jälkeen siirtokarjalaisten kokemuksista voitiin jälleen puhua vapaasti ja julkisesti (ks. esim. Savolainen 2017), ja Karjalaan ja Karjala-kysymykseen liittyviä mielipiteitä ja tunteita voitiin vapaasti ilmaista esimerkiksi suomalaisessa lehdistössä (ks. Laine ja van der Velde 2017), joka oli harjoittanut itsesensuuria kylmän sodan aikana.

Suomessa on monia järjestöjä, joiden tarkoituksena on vaalia muistoa elämästä menetetyllä alueella (ks. esim. Karjalan Liitto 2019). Lisäksi on joitakin marginaalijärjestöjä, jotka kampanjoivat luovutetun Karjalan Suomelle palauttamisen puolesta. Joillekin ihmisille ja ihmisryhmille Karjala ei ole vain menetetty alue, vaan se merkitsee myös menetettyä kulttuuriperintöä ja merkityksellisiä paikkoja kuten koteja ja yhteisöjä. Jälkimmäisten menettäminen vaikeuttaa ensin mainituista ylipääsemistä, ja siksi Karjalasta puhutaankin yhä kuin se olisi osa Suomea - jos ei alueellisesti, niin kulttuurisesti tai henkisesti (ks. Laine \& van der Velde 2017). Siinä missä joillekin ihmisille luovutettu Karjala voi olla melko "etäinen" ja merkityksetön, toisille sen menettäminen voi yhä aiheuttaa "alueellista haamukipua" (territorial phamtom pains), joka on kansallisvaltion tason vastine menetetyn raajan aiheuttamalle kivulle (Billé 2014; 2016).

Luovutetun Karjalan muistot matkustivat toisen maailmansodan jälkeisen rajan yli niiden suomalaisten mukana, jotka pakotettiin lähtemään alueelta. He muodostivat Suomessa uuden väestöryhmän, Karjalan evakot, jotka sopeutuivat laajempaan suomalaiseen yhteiskuntaan samalla kun vaalivat omia kulttuuriperinteitään (ks. Niukko 2009, 65). Karjalan evakkojen kokemuksia, tarinoita ja muistoja on tutkittu ja julkaistu myöskin englanniksi melko laajasti 2000-luvulla (mm. Armstrong 2004; Böök 2004; Fingerroos 2008; Niukko 2009). Myös arkistoidut muistelmat ja selviytyneiden evakkojen haastattelut tuottavat jatkuvasti uutta tutkimusta (ks. esim. Savolainen 2017). Aiemman tutkimuksen mukaan Karjalan evakot idealisoivat menetettyjä kotialueitaan ja kuvailevat niitä "jäljittelemättömän kauniiksi paikoiksi”" kieltäen "kaiken, mikä sotaa edeltävässä elämässä oli kielteistä" (Böök 2004, 40).

Luovutetun Karjalan rakentumista "täydelliseksi" ja "kadotetuksi" paikaksi, jossa aika on pysähtynyt, edesauttoi se, että raja-alue oli suljettu ulkomaalaisilta matkailijoilta 1980-luvun lopulle asti (Böök 2004, 33). Karjalan evakoilla ja muilla suomalaisilla ei siis ollut ennen sitä pääsyä luovutetun Karjalan todellisuuteen, ja heidän mielissään säilyneet kuvat, käsitykset ja muistot noista paikoista säilyivät muuttumattomina. Nämä jähmettyneet Karjala-muistot, jotka muodostuivat lähes välittömästi toisen maailmansodan jälkeen, pysyivät muuttumattomina neuvostoajan loppuun asti. Ne ovat matkustaneet ajan halki ja siirtyneet sukupolvelta toiselle Karjalan evakkoperheiden kertomusten välityksellä (ks. Armstrong 2004) sekä järjestelmällisten keruiden ja arkistoinnin sekä lukuisten erilaisten julkaisujen kuten iltapäivälehtien ja tieteellisten julkaisujen avulla. 


\section{Nuorten kansalliset ja alueelliset käsitykset}

Ihmiset tutustuvat tiettyihin kulttuurisiin tapoihin ja kognitiivisiin representaatioihin heidän kansakunnastaan ja valtiostaan varhaislapsuudesta lähtien (Scourfield et al. 2006). Viimeaikaisessa tutkimuksessa on korostettu lasten ja nuorten asemaa aktiivisina ja tärkeinä toimijoina heidän sosiaalisissa ja kulttuurisissa ympäristöissään (Spyrou \& Christou 2014; McKnight \& Leonard 2014; Habashi 2014). Nuoret eivät pelkästään omaksu passiivisesti kansallisvaltion( $\mathrm{sa}$ ) representaatioita, vaan he osallistuvat aktiivisesti niistä neuvottelemiseen ja niiden rakentamiseen (Jukarainen 2003, 217; ks. myös Habashi 2014). Viimeaikaisissa tutkimuksissa on kannustettu "tarkastelemaan sitä, miten lapset ovat yhteydessä paikkoihin ja alueisiin ja miten he muodostavat merkityksiä arkielämässään" (Spyrou \& Christou 2014, 5). Tällainen tutkimus voi lisätä ymmärrystämme raja-alueista ja rajoihin liittyvistä sosiaalisista ja yhteiskunnallisista prosesseista. Näiden asioiden tutkimuksessa nuorten rooli on perinteisesti jäänyt vaille huomiota.

Se, miten nuoret sisäistävät ja ilmaisevat kiistanalaiseen alueeseen liittyviä merkityksiä, narratiiveja ja mielikuvia, ei ole suoraviivaista. Tutkiessaan belfastilaisten nuorten näkemyksiä fokusryhmämenetelmän avulla (muiden menetelmien ohella) Martina McKnight ja Madeleine Leonard $(2014,170)$ saivat selville, että nuoret voivat yhtä aikaa hyväksyä "konfliktin jälkeiset jakamisen ja normalisoinnin narratiivit" ja samalla osoittaa "tukea tilan eksklusiiviselle käytölle". Aiemmissa tutkimuksissa, joissa on tarkasteltu nuorten käsityksiä rajasta ja raja-alueen "toisesta puolesta" Suomen ja Venäjän raja-alueella, on tullut vastaavanlaisia moniulotteisia vastauksia. Pirkkoliisa Ahponen osoitti tutkimuksessaan (2011), että kun suomalaiset, hänen tutkimuksessaan yliopisto-opiskelijanuoret ylittivät Suomen ja Venäjän välisen rajan entiseen Suomen Karjalaan ja pohtivat kokemustaan, heidän käsityksensä "toisesta" ja "Karjalasta" monimutkaistuivat. Tuoreessa tutkimuksessa, joka selvitti mentaalikarttojen avulla Suomen ja Venäjän rajaa lähellä Etelä-Karjalassa ja Leningradin alueella asuvien 9-15-vuotiaiden nuorten näkemyksiä, havaittiin, että osallistujat Suomessa ja Venäjällä sekä kuvasivat rajaa rajanylityspaikkana ja näkivät yhtäläisyyksiä "heidän ja rajan toisen puolen" välillä että rakensivat eroavaisuuksia rajan eri puolten välille (Kaisto \& Brednikova 2019). Sitä vastoin suomalaisia ja venäläisiä rajaseudulla eläviä nuoria 1990-luvulla tutkinut Pirjo Jukarainen (2003) sai selville, että Suomen Pohjois- ja Etelä-Karjalassa sekä Venäjän Viipurissa asuvat nuoret pitivät rajan eri puolia kulttuurisesti ja kielellisesti selvästi erilaisina, ja heidän asenteensa rajanaapureita kohtaan olivat hyvin ennakkoluuloisia ja varautuneita. Suomalaisnuorten asenteet saattavat olla yhteydessä siihen, että tuolloin vuosikymmeniä suljettuna ollut raja oli juuri avattu ja saattoi aiheuttaa pelkoa (ibid).

Edellä esitellyt tutkimukset korostavat nuorten toimijuutta kansallisten ja alueellisten käsitysten muodostamisessa, ja ne antavat viitteitä siitä, minkälaisia käsityksiä tämän päivän ja lähimenneisyyden suomalaisilla nuorilla on valtioiden rajat ylittävästä Karjalan alueesta, jota määrittää sen läpi kulkeva raja. Tämä artikkeli täydentää olemassa olevaa tutkimusta tarkastelemalla fokusryhmien avulla, millaisia merkityksiä nuoret liittävät Karjalaan sekä konkreettisena alueena että abstraktin mielikuvien tasolla. Seuraavassa osiossa esitellään tutkimuksen käsitteellinen viitekehys, jota käytettiin näiden merkitysten analysointiin, ymmärtämiseen ja kontekstualisointiin. 


\section{Tilallinen sosialisaatio, arkipäivän nationalismi ja alueellinen haamukipu}

Tämä tutkimus kietoutuu kysymykseen siitä, miten muistot"menetetystä" alueesta voivat olla kovin merkittäviä tietyille ihmisryhmille. Avainkäsite tämän kysymyksen ymmärtämiseen on tilallinen sosialisaatio. Suomalainen maantieteilijä Anssi Paasi on muiden tutkijoiden ohella käyttänyt tilallisen sosialisaation käsitettä keinona ymmärtää ja analysoida yksilön sosiaalistumista tiettyyn alueellisesti rajattuun tilalliseen kokonaisuuteen, kuten kansallisvaltioon (ks. Paasi 1996; 2016). Tilallinen sosialisaatio on dynaaminen ja jatkuva prosessi, jonka avulla ymmärrystä "normatiivisesta alueelle tyypillisestä elämäntavasta" luodaan jatkuvasti uudelleen sekä arkisten ja epämuodollisten että muodollisten ja institutionaalistuneiden käytäntöjen kautta (Kuusisto-Arponen 2003, 161; Kallio 2014, 211). Tilallista sosialisaatiota tapahtuu hallinnon, politiikan, koulutuksen, median, kirjallisuuden, muistin paikkojen ja yksilön sisäistämien yhteisten alueellisten narratiivien ja jaettujen perinteiden kautta (Paasi 1996; 2016). Paasin mukaan kansallinen taso saattaa olla usein kaikista merkittävin tilallisessa sosialisaatiossa, ja hänen mukaansa tilallinen sosialisaatio ja nationalismi ovat olennaisesti yhteydessä toisiinsa (Paasi 2016, 24).

Tilallinen sosialisaatio alkaa jo varhaislapsuudessa (Kallio 2014), ja muun muassa Paasi on tutkinut, millä keinoin ja tavoin samassa valtiossa elävät nuoret ovat tilallisesti sosiaalistuneita. Paasi (1996; 2016) on käyttänyt koulukirjoja esimerkkinä ylhäältä alaspäin suuntautuvasta tilallista sosialisaatiosta, joka kohdistuu erityisesti nuoriin. Kirsi-Pauliina Kallio (2014) on tarkastellut nuoria aktiivisina sosiaalisina toimijoina soveltaen tilallisen sosialisaation käsitettä suomalaisnuorten poliittisen kypsymisen tutkimukseen ja havainnut, että nuorten käsitykset kansallisen viitekehyksen merkityksestä vaihtelivat (ibid., 218). Hänen mukaansa tämä viittaa siihen, että "edes kaikkein voimakkaimmat ja aina läsnäolevat tilallisen sosialisaation prosessit eivät johda samuuteen, vaan luovat keskinäisiä eroja, joiden perusteella nuoret vaihtelevasti sijoittavat itsensä elettyihin maailmoihinsa" (ibid.). Tilallisen sosialisaation käsite sopii äärimmäisen hyvin nuorten suomalaisten Karjalaan yhdistämien merkitysten analysoimiseen, sillä tilallinen sosialisaatio selittää hyvin mekanismeja, joiden myötä ihmisille kehittyy käsitys siitä, "minne ja kenelle paikat kuuluvat" yksilöllisten, paikallisten ja kansallisten käsitysten mukaan.

Toinen hyödyllinen käsite Karjalaan liitettyjen merkitysten tarkasteluun on "arkipäivän (banaali) nationalismi" - tapa, jolla kansakunta ja sen merkitys ovat läsnä arjessa (Billig 1995). Arkipäivän nationalismi ilmenee lukemattomin eri tavoin, kuten esimerkiksi tapana viitata "meihin", puhuttaessa kansallisesta alueesta (Paasi 2016, 23). Arkipäivän nationalismia voi olla vaikea erottaa niin sanotusta "kuumasta nationalismista" (hot nationalism), eli nationalismista sen äärimmäisimmässä, dynaamisimmassa ja väkivaltaisimmassa muodossaan; arkipäiväiseltä nationalismilta vaikuttavat tavat voivat aiheuttaa tai merkitä piilevää kuumaa nationalismia, ja päinvastoin (ks. Paasi 2016). Sen lisäksi, että Karjalaa pidetään Suomen menetettynä alueena, sillä on myös useita arkipäiväisiä assosiaatioita: se yhdistetään tiettyihin perinteisiin suomalaisiin ruokiin (ks. Wells, 2016), suosittu olutmerkki on nimeltään "Karjala" ja suomalaisissa popkappaleissa lauletaan "Karjalan saamisesta takaisin" (JVG feat. Freeman 2012; Portion Boys 2017). Nämä ilmeisen arkipäiväiset assosiaatiot voivat aiheuttaa voimakkaampia nationalistisia reaktioita, sillä ne muistuttavat Karjalan olevan menetetty alue. Karjala on esimerkki tapauksesta, jossa (mahdollisesti) kuuma nationalismi sekoittuu ja sotkeutuu arkipäiväiseen. 
Tilallinen sosialisaatio ja arkipäivän nationalismi ovat yhteydessä alueellisen haamukivun (Billé 2014; 2016) käsitteeseen. Alueet, jotka ovat merkittäviä kansalliselle itseymmärrykselle voivat aiheuttaa alueellista haamukipua, kun ne erotetaan kansakunnan "vartalosta" valtakunnan rajojen siirtämisen myötä. Tällainen kipu voi aiheuttaa "nostalgisia tunnetiloja, jotka ilmenevät kulttuurielämässä ja jotka toisinaan johtavat voimakkaisiin yhteiskunnallisiin liikkeisiin. Näillä liikkeillä on kansalliskiihkoisia iskulauseita, kuten uudelleenyhdistäminen valtioon, jonka osa alue on ollut, tai entisten rajojen palauttaminen" (Kolosov 2015, 37). Karjalan menettäminen aiheutti tällaisia alueellisia haamukipuja, koska aluetta pidettiin tärkeänä kansalliselle identiteetille (Laine \& van der Velde 2017, 67). Ajatus siitä, että Karjalan pitäisi oikeutetusti olla osa Suomea, on säilynyt joissakin piireissä, ja sitä on pidetty esillä mediassa ja muissa narratiiveissa huolimatta siitä, että Karjala on ollut irti kansallisesta vartalostaan jo yli 70 vuotta (ibid. 69-71; Paasi 2016, 25). Karjala on "haamualue": vaikka se ei ole enää osa Suomen valtiota, joillekin suomalaisille ja kansallisen diskurssin tasolla se on tunnetasolla edelleen "kiinni kansallisessa vartalossaan" (Billé 2016, 18).

\section{Pohdintaa Karjalasta Suomen lukiolaisten kanssa}

Artikkelissa analysoitu aineisto koostuu 325 lukiolaisnuoren (iältään 16-19 vuotta) fokusryhmähaastatteluista, jotka tehtiin vuonna 2017. Mukana oli nuoria 11 eri kaupungista ympäri Suomen. ${ }^{1}$ Fokusryhmissä kysyin osallistujilta: "Mitä sinä tiedät Karjalasta?", "Mitä tulee mieleesi kun kuulet sanan 'Karjala'?", "Missä on Karjala?", "Onko sinulla iso- tai isoisovanhempia tai muita sukulaisia Karjalasta?", "Jos on, mistä he tulivat?"

Fokusryhmämenetelmää on käytetty onnistuneesti tutkimuksissa, joissa on tarkasteltu nuorten samastumista paikkoihin (ks. Kuusisto-Arponen 2003; McKnight \& Leonard 2014). Tutkimuksessani fokusryhmämenetelmän mahdollistama ryhmädynamiikka on avainasemassa. Kaltaisilleni tutkijoille, "jotka ovat kiinnostuneita sosiaalisesti konstruoidusta tiedon luonteesta", tämä fokusryhmien ominaisuus tekee niistä ihanteellisen tutkimusmenetelmän (Cameron 2005, 117). Fokusryhmissä sain omakohtaisesti todistaa Karjalaan liittyvien käsitysten yhteistä konstruointia ja ilmaisemista.

Kaikki osallistujat altistuivat fokusryhmien aikaan jatkuvasti tilallisen sosialisaation prosesseille suomalaisen muodollisen koulutuksen kautta. Lisäksi, koska osallistujat asuivat Suomessa, he altistuivat epävirallisille ja ilmeisen arkipäiväisille tilallisen sosialisaation prosesseille esimerkiksi suomalaisen median kautta. Osallistujat jakoivat saman sosialisaatioympäristön, jossa heitä ympäröivät jatkuvasti meneillään olevat, sekä ylhäältä alas että alhaalta ylös suuntautuvat prosessit, jotka pyrkivät sosiaalistamaan heitä tilallisesti (ks. Kuusisto-Arponen 2003, 161; Kallio 2014, 211). Osallistujien henkilökohtaisia taustatietoja (esimerkiksi olivatko he asuneet Suomessa koko elämänsä) ei kerätty osallistujilta, joten taustan ei nähdä vaikuttaneen tuloksiin yksilöiden välistä normaalia differentiaatiota enempää, mikä joka tapauksessa on huomioitu tavassa, jolla tilallisen sosialisaation prosessit tuottavat "yhteenkuuluvia mutta ainutlaatuisia" ihmisiä (ks. Kallio 2014, 215).

Analysoin fokusryhmäaineistoni temaattisella sisällönanalyysilla (Thematic Content Analysis, TCA), joka on "menetelmä, jonka avulla voidaan tunnistaa ja analysoida aineistossa esiintyviä malleja (teemoja) ja raportoida niistä" (Braun \& Clarke 2006, 79). Teeman tärkeys ei riipu siitä, kuinka monta kertaa teema esiintyy aineistossa, vaan ennemminkin siitä, tuoko se esiin jotain tärkeää suhteessa tutkimuskysymykseen (ibid.). Analyysiprosessi kehittyi kuvailusta," jossa aineisto on vain referoitu ja pistetty järjestykseen semanttisen sisällön si- 
sältämien mallien ilmaisemiseksi", tulkintaan, "jolla pyritään teoretisoimaan mallien tärkeys ja niiden laajempia merkityksiä ja johtopäätöksiä” (ibid).

\section{Suomen nykynuorten Karjala}

Kolme toisiinsa liittyvää pääteemaa nousi esiin fokusryhmäaineistosta. Teemat olivat: Karjalan merkitys osallistujille, Karjalan läsnäolo osallistujien arkielämässä ja Karjalan menetys, joka yhdistyi ajatukseen Karjalan palauttamisesta. Karjalan merkityksestä keskusteltaessa osallistujat vastasivat usein Suomen kansallisesta viitekehyksestä käsin: "[Karjala] oli iso osa Suomea ja se menetettiin sodassa, [ja] sieltä tuli sodassa paljon ihmisiä tänne Suomeen" (Joensuu 1 NO1)2, "Karjala on ollut Suomelle niinku tosi tärkeä alue koko Suomen tai Ruotsin historian ajan ja siellä on paljon meiän niinkö muinaishistoriaa" (Oulu 1 NO1). Lisäksi osallistujat ymmärsivät Karjalan alueena, joka "on jo aika kauan ollut tällainen, kiistelty alue Suomen ja Neuvostoliiton/Venäjän rajalla" (Oulu 3 NO).

Joillekin osallistujille Karjala oli henkilökohtaisesti merkittävä, ja he arvostivat sitä, että siitä keskusteltiin fokusryhmässä: "Karjalan alue on [...] ns. vahva osa identiteettiäni ja oli mukavaa kuulla siitä lisää ja että se kiinnostaa muitakin kovasti” (Vaasa 4 P4)3. Joidenkin osallistujien mielestä Karjalan merkitykselle pitäisi antaa enemmän tunnustusta: erään osallistujan mukaan siitä "puhutaan niin vähän" (Helsinki 1 Y2)4, ja toinen oli sitä mieltä, että "on mielenkiintoista kuulla Karjalasta, sillä vain harvoin tapaa ihmisiä, jotka puhuvat siitä” (Turku 1 P12).

Karjala ei vaikuttanut merkitsevän osallistujille kadotettua paratiisia, kuten Karjala usein esitetään evakkojen kertomuksissa (ks. edellä). Osallistujat eivät idealisoineet sotaa edeltävää Karjalaa, ja yksi osallistuja jopa kritisoi kyseisiä narratiiveja ja kommentoi, että tarinoissa, joita hän on kuullut Karjalasta "aina sanotaan, että se on paljon parempi kuin Suomi ja vihreämpi ja kauniimpi" (Oulu $1 \mathrm{MO} 4)$. Osallistujat puhuivat nykypäivän Karjalasta melko kielteiseen sävyyn, mikä on sotaa edeltäneen idealisoidun mielikuvan vastakohta: "Nykyään se on aika köyhää aluetta" (Helsinki 1 MO5), "aivan kuollu (...) ku Siperia" (Joensuu 3 NO), "Karjala ei oo pystyny kehittyy. Jos se olis osa Suomee ni se ois varmaan voinu kehittyyki siitä" (Helsinki $2 \mathrm{MO}$ ), "on se menny vähä huonoon kuntoon sen takii ku se ei oo enää Suomella" (Vaasa 4 NO). Näille osallistujille Karjala merkitsee aluetta, johon liittyy kielteisiä mielikuvia. Joissakin tapauksissa tämä on yhdistetty siihen, että Karjala ei ole enää osa Suomea.

Fokusryhmäaineiston toinen teema on läsnäolo, eli tavat, joilla Karjala on läsnä osallistujien arkielämässä. Osallistujat yhdistivät Karjalan usein tiettyihin ruokiin, joita he kohtaavat säännöllisesti arkielämässään: 'Kun kuulen [sanan] 'Karjala', ajattelen kaikkea karjalaista ruokaa [...] Niinku karjalanpiirakoita, meillä on niitä itse asiassa koulussa tänään" (Oulu 3 NO3). Ruoan lisäksi osallistujat yhdistivät Karjalan myös olueen (oletettavasti Karjalaolutmerkin takia). Osallistujat liittivät Karjalaan usein myös "aika montaki biisiä" (Oulu 4 MO7) tai "pari hauskaa laulua" (Turku 2 NO), mikä osoittaa, että laulut ovat yksi tapa, jolla Karjala on läsnä nuorten arkielämässä. Jotkut osallistujat alkoivat jopa laulaa näitä lauluja oma-aloitteisesti ryhmähaastattelun aikana. Tällaisia osallistujien ilmeisen arkipäiväisiä viittauksia Karjalan läsnäoloon heidän arkielämässään ei pitäisi hylkiä tai jättää huomiotta. $\mathrm{Ne}$ voivat olla yksi pääasiallisista yhteyksistä, joissa osallistujat törmäävät Karjalan käsitteeseen ja alkavat ymmärtää sen merkityksen (tai merkityksettömyyden) itselleen ja laajemmalle kulttuurille, jossa he kasvavat. 
Merkityksen ja läsnäolon teemat kietoutuivat toisiinsa niillä osallistujilla, joilla oli henkilökohtaisia perhesiteitä Karjalaan. Suvun tarinat evakuoinnista ja pakkosiirrosta saattavat tehdä Karjalasta osallistujille läsnäolevan ja merkityksellisen paikan, josta he ovat kuulleet vanhemmilta perheenjäseniltään ja jolla saattaa olla heille henkilökohtaista merkitystä osana heidän taustaansa. Seuraava katkelma on yksityiskohtainen kuvaus osallistujan suvun yhteydestä Karjalaan:

\begin{abstract}
Mul tulee tosi vahvasti mieleen meijän siis suku [kun kuulin sanan "Karjala"]. [...] meijän suku on siis Karjalasta, Viipurista. Ja sitten Koivistolta. ${ }^{5}$ Sieltä. Ja siel on Koivistolla ihan meidän periaatteessa sukutalo edelleen. Ei oo meidän omistukses enää tietenkään. Jääny sillon jatkosodan jälkeen sinne. Mutta on se talo edelleen siellä pystyssä. Mutta siis... Mun papan vanhemmat ja mun papan isovanhemmat on kotosin siis Karjalasta. [...]ja nää [perheenjäsenet] jotka asu Koivistolla niin kävi jopa valokuvaamassa, valokuvauttamassa itsensä Viipurissa, koska se oli hieno paikka. Sinne mentiin niinku, vähän niinku pääkaupunkiin. Et silleen meil on tosi vahvat juuret sinne, ni mulla tulee mieleen mun äiti ja mun perhe Karjalast ensimmäisenä. (Helsinki 2 NO3.)
\end{abstract}

Karjala on tärkeä tälle tutkimuksen osallistujalle, koska se liittyy hänen sukuhistoriaansa. Osallistuja on ottanut sukunsa muistot Karjalasta omikseen: hän kuvailee Viipuria ikään kuin hän itse olisi kokenut sen. Karjala on myös läsnäoloa; osallistuja "tuo Karjalan lähelle" tarinan yksityiskohtien avulla, mikä on tyypillistä evakkokertomuksille (Armstrong 2004, 131). Osallistuja osoittaa toimijuutensa suhteessa historialliseen narratiiviin kertomalla ulkopuoliselle tutkijalle henkilökohtaisen narratiivin, joka on siirtynyt sukupolvelta toiselle ja joka nyt kerrottuna heijastaa hänen henkilökohtaisia käsityksiään (ks. Habashi 2014, 426).

Kolmas teema on menetys. Karjalaa ympäröivä menetyksen tunne vaikuttaa koskettavan vielä 70 vuotta myöhemmin. Ryhmähaastattelujen päätteeksi osallistujia pyydettiin kirjoittamaan ylös tärkeimmät asiat, joista heidän ryhmässään oli puhuttu. Yksi osallistuja kirjoitti: "Karjala menetettiin, mikä oli edelleen katkera asia Suomalaisille" (Joensuu 1 Y3), ja toinen kirjoitti: "Tärkeää oli huomata se, että Viipuriin ja Karjalaan liittyy edelleen paljon muistoja ja kaipaustakin" (Oulu 1 Y5). Jopa tosiseikkoihin perustuvat ilmaukset, jotka viittasivat Karjalan menettämiseen, korostivat Karjalan suomalaisuutta ja "meitä" kansallisena ryhmänä, joka menetti alueen: "Se oli alun perin osa Suomea mutta sitten meidän piti tavallaan antaa se venäläisille" (Turku 1 MO2).

Kun osallistujilta kysyttiin, mitä he yhdistävät sanaan Karjala, iskulause "Karjala takaisin" nousi usein esiin, toisinaan välittömänä vastauksena. Yksi osallistuja täsmensi, että Karjalasta hänelle tuli mieleen "Karjala takaisin! Suomalainen sisu ja kaikki tällaset" (Lahti 4 MO3). Kun häneltä kysyttiin, missä hän oli kuullut iskulauseen, hän vastasi: 'No se on vähä sellanen, nationalistinen juttu se liittyy, suomalaiseen kulttuuriin". Toinen osallistuja lisäsi: "Eikse [Karjala takaisin] oo jossai biisissä?... 'Voitetaan Karjala takaisin' tai jotai semmosta" (Lahti 4 NO1). Kommentti osoittaa, kuinka tähän nationalistiseen ja revansistiseen iskulauseeseen voi törmätä arkipäiväisissä muodoissa, kuten esimerkiksi suomalaisissa popkappaleissa (laulun esittäjä on JVG feat. Freeman, 2012). Yksi osallistuja yhdisti Karjala-merkkisen oluen ajatukseen Karjalan palauttamisesta sanomalla "Karjala takaisin otetaan pullo kerrallaan" (Turku 3 NO1). Hän kertoi kuulleensa iskulauseen isältään. Myöhemmin hän lisäsi vakavampaan sävyyn, että "Karjalahan oli Suomen aluetta, mut sit me menetettiin se Venäjään". 
Eräs osallistuja kieltää yhteenvedossaan ajatuksen Karjalan palauttamisesta ja kansallisen menetyksen tunteen olemassaolosta, mutta siitä huolimatta hän tunnustaa Karjalan merkityksen: "Voiko ikinä saada Karjalan takaisin? - Ei. Ei enää suomalaisia kaipaa. Tärkeätä oli se, että puhuttiin Karjalasta" (Oulu 1 Y4). Yksi osallistuja yhdisti Karjalan menettämisen tietynlaiseen käsitykseen kansallisesta identiteetistä ja kirjoitti: "Kuuluu suomalaisuuteen haikailla sodassa menetettyjä alueita takaisin" (Rovaniemi 2 Y5). Yksi osallistuja selitti minulle, ulkopuoliselle ulkomaiselle tutkijalle, että "monien suomalaisten mielestä [Karjalan] pitäisi kuulua Suomelle [...] haluaisimme sen takaisin, mutta todennäköisesti emme koskaan saa" (Oulu 3 NO2). Osallistuja puhuu kuvitteellisen, kansallisen "meidän" puolesta, mikä on arkipäiväisen nationalismin avainmekanismeja (Paasi 2016, 22). Hän ilmaisee ajatuksen, jonka mukaan Karjalan "pitäisi olla" osa Suomea, mutta sen "takaisin saaminen" ei ole realistinen toive. Tämä on esimerkki tapauksesta, jossa osallistuja käyttää toimijuuttaan välittääkseen eteenpäin version kansallisen tason narratiivista, johon heijastuvat hänen omat käsityksensä ja näkökulmansa (ks. Habashi 2014, 426).

\section{Nationalismi ja Suomen nykynuorten käsitykset Karjalasta}

Tutkimuksen osallistujien kommentit viittasivat kansallisen tason prosesseihin, joihin muun muassa muodollinen koulutus kuuluu ja jotka sosiaalistavat osallistujia tilallisesti Suomen (menneeseen ja nykyiseen) alueeseen ja saavat heidät tuntemaan itsensä suomalaisiksi. Yhdessä ryhmistä keskusteltiin siitä, mistä osallistujat olivat saaneet tietoa Karjalasta. Vastausten mukaan osallistujat kuulivat Karjalasta koulussa, mutta lisäksi se oli myös "yleistietoa" (Oulu 3 NO1) tai "sisäistä tietoa" (Oulu 3 NO2), ja että "olisi outoa jos suomalaisena et olisi kuullut Karjalasta" (Oulu 3 NO4). Osallistujat tiedostivat, että Karjalaa koskevaa tietoa ei ole saatavilla vain evakkosuvuissa vaan myös suomalaisessa yhteiskunnassa laajemmin, kuten yksi osallistuja selitti: "[Karjalasta] on paljon tarinoita lehdissä ja jopa koulukirjoissa" (Rovaniemi 3 MO2).

Se, että osallistujat kuvailevat nykypäivän Karjalaa melko kielteiseen sävyyn, osoittaa sen, että tietyillä mediassa kiertävillä diskursseilla (jotka muodostavat merkittävän osan tilallisen sosialisaation prosessista), on ollut vaikutusta siihen, mitä merkityksiä osallistujat antavat Karjalalle. Näin tehdessään osallistujat toistavat suomalaisessa mediadiskurssissa esiintyvää vähäisesti kritisoitua mielikuvaa, jonka mukaan luovutettu Karjala oli suomalaisena täydellinen ja venäläisenä se on täydellisen pilalla: "Epäsuora viesti on, että Suomen vallan alla tulokset olisivat olleet erilaisia, eli parempia” (Böök 2004, 42). Osallistujat vaikuttavat omaksuneen tämän viestin. Myös muissa tutkimuksissa nuoret ovat ilmaisseet kielteisiä käsityksiä koskien Suomen ja Venäjän välisen rajan "toista puolta" (eli menetettyä Karjalaa), mikä viittaa siihen, että mielikuva saattaa olla levinnyt laajalle nuorten joukossa. Nuoria Suomen raja-alueella tutkineet Jukarainen (2003) sekä osittain myös Virpi Kaisto ja Olga Bredinova (2019) kohtasivat samanlaisia negatiivisia mielikuvia, esimerkiksi että: "Suomen puolella olevien talojen sanottiin olevan hyvässä kunnossa, kun taas Venäjän puolella olevat talot olivat rappeutuneita" (ibid., 10). Ahponen $(2011,154)$ tutki menetetyssä Karjalassa vierailevia nuoria ja havaitsi, että "vierailijat siirsivät itsensä kuvitteelliseen ja stereotyyppiseen 'meidän' menneisyyteen vertaillakseen tuttuja ja vieraita piirteitä rajan toisella puolella”. Tämän tutkimuksen tulokset mukailevat pitkälti näiden tutkimusten tuloksia. Kuten Jukarainen $(2003,222)$ on huomauttanut, "toiseen" valtioon liittyvää "sosiaalisesti opittujen stereotypioiden toistamista", jota nuoret tekevät, ei saisi pitää "harmittomana tai 
neutraalina, vaan ongelmallisena ja poliittisena luokitteluna", joka voi muodostaa pohjan ksenofobiselle ajattelulle ja käytökselle.

Vaikka tulokset osoittivat, että osallistujilla oli jaettuja käsityksiä Karjalasta - johtuen kansallisen tason tilallisen sosialisaation vaikutuksista -osallistujat myös antoivat Karjalalle erilaisia ja tärkeydeltään eritasoisia merkityksiä. Tämä johtuu tilallisen sosialisaation yksilöllisestä ulottuvuudesta (ks. Kallio 2014), jonka mukaan tilallisen sosialisaation eri keinot (esim. oppitunnit, aikakauslehdet) vaikuttavat eri tavoin eri yksilöihin. Tämän tutkimuksen tulokset tukevat yksilöä aktiivisena toimijana pitäviä väitteitä, sillä tulosten mukaan nuoret voivat olla sisäistämättä tiettyjä "ylhäältä alas" suuntautuvia tilallisen sosialisaation narratiiveja. Tämä ei välttämättä ole aktiivista vastustusta tai kieltämistä, vaan johtuu ennemminkin siitä, ettei yksilö muista tai pidä kyseistä tietoa tärkeänä. Tutkimustulokset peilaavat myös Kaiston ja Brednikovan $(2019,15)$ tuloksia. He käyttivät tilallisen sosialisaation käsitettä suomalais- ja venäläisnuorten tekemien mentaalikarttojen analysoimiseen ja saivat selville, että osallistujien käsitykset Karjalan raja-alueesta vaihtelivat suuresti yksilöiden välillä. Tämä osoitti, että osallistujat "kuuluvat kansallisesti ja paikallisesti yhteen, mutta ajattelevat ja toimivat itsenäisesti”.

Eri fokusryhmistä saadut vastaukset korostivat sitä, että myös arkipäiväinen nationalismi vaikuttaa merkittävästi suomalaisten nuorten käsityksiin Karjalasta. On väitetty, että lapset altistuvat "arkipäiväisen nationalismin monille eri muodoille" ja "elävät ympäristöissä, joissa kansalliset erot ovat... hyvin vahvasti esillä” (Scourfield et al. 2006, 64). Tämän tutkimuksen tulokset näyttävät, missä määrin arkipäiväinen nationalismi vaikuttaa tutkimuksen osallistujiin. Osallistujat yhdistelivät vapaasti ja humoristisesti arkisia, jokapäiväisiä mielleyhtymiä, kuten Karjala-oluen, joka kertoo Karjalan läsnäolosta heidän arjessaan, vakavampaan ymmärrykseen menetetystä alueesta, joka oli "Suomella... ekana" (Turku 3 NO). Yhdistelemällä erilaisia käsityksiä "Karjalasta" osallistujat osoittivat kykenevänsä osallistumaan kansallisiin diskursseihin sekä luomaan omat käsityksensä niistä (ks. Habashi 2014, 424 ja 426).

Eri ryhmäkeskusteluissa oltiin tietoisia siitä, että "Karjala-juttu" (Lahti 4 MO) liittyy suomalaiseen nationalismiin, ja keskusteluissa mainittiin myös, että oltiin tai ei oltu "Karjala takaisin -tyylinen ihminen" (Oulu 6 NO1). Osallistujat olivat siis tietoisia siitä, että "tietyntyyppiset ihmiset" kannattavat Karjalan palauttamista Suomelle. Jotkut suhtautuivat Karjalaan nostalgisella kaipuulla, jota sävytti revansistinen ja turha toivo, että Karjalan alueen palauttaminen voisi toimia hyvityksenä alueen (kuvitellun) 1930-luvun lopun yhteisö- ja kulttuurielämän menetetykselle. Osallistujat perustelivat myös, miksi jotkut ihmiset haluavat Karjalan takaisin: "ku venäläiset sai sen [Karjalan] ni se nosti sen (...) ni semmonen kansallissymboli Suomelle" (Joensuu 1 MO2). Nämä vastaukset osoittavat osallistujien olevan tietoisia "kuumasta" nationalismista, jota saattaa lietsoa keskustelu Karjalan menettämisestä ja Suomen osallistumisesta toiseen maailmansotaan (ks. Paasi 2016, 25).

Osallistujat käyttivät "me" suomalaiset -ilmausta kuvaillessaan Karjalan menettämistä; he sisällyttivät näin itsensä ryhmään, joka on kokenut menetyksen, vaikka ovat itse syntyneet vuosikymmeniä myöhemmin. Keskusteluissa viitattiin siihen, mistä tämä voisi johtua. Eräs osallistuja kertoi, että hän kuuli iskulauseen "Karjala takaisin" isältään. Tieto on siis periytynyt, kuten mahdollisesti myös tunne siitä, että Suomella olisi edelleen Karjalan "omistusoikeus". Vaikka osallistujat toistivat iskulauseen "Karjala takaisin" usein välittömänä vastauksena kysymykseen, mitä sanasta "Karjala" tulee mieleen, he eivät kuitenkaan ilmaisseet oikeasti haaveilevansa luovutetulle alueelle palaamisesta tai alueen palauttamisesta Suomelle. Havainto on samansuuntainen kuin muissa pakolaisten jälkeläisiä tarkastelevissa 
tutkimuksissa, joiden mukaan nuorilla ei ole "edellisen sukupolven halua palata kotiin" (Habashi 2014, 422).

Suomalaisissa diskursseissa esiintyvä narratiivi, jonka mukaan Karjala on menetetty paratiisi, voi aiheuttaa tietynlaisia tunteita, kuten menetystä ja nationalistista kiihkoa, mutta kuten tämä suomalaisia nuoria käsittelevä tutkimus osoittaa, yksilöillä tai ryhmillä ei välttämättä ole erityisiä tunnereaktioita Karjalan menetykseen liittyen. Osallistujat yhdistivät Karjalan iskulauseeseen "Karjala takaisin", mutta he yhdistivät iskulauseen ennemmin olueen ja popkappaleisiin kuin suruun tai tuskaan. Aiemman tutkimuksen mukaan suomalaisissa mediadiskursseissa "Karjalan aiheuttama arpi on pikkuhiljaa paranemassa ja häviämässä ihmisten muistoista" (Laine \& van der Velde 2017), mitä tukee tämän tutkimuksen tuloksista se, että osallistujat eivät pitäneet Karjalaa alueena tai käsitteenä, joka olisi aiheuttanut heille "alueellista haamukipua".

\section{Karjalan merkitys Suomen nykynuorille}

Karjala on ollut Suomen kansakunnan rakentamiselle sekä kansallisille ja alueellisille käsityksille keskeinen alue, joka "irrotettiin" kansallisesta vartalosta toisen maailmansodan jälkeisten rajalinjojen myötä. Tässä artikkelissa on tutkittu, minkälaisia merkityksiä nykypäivän nuoret Suomessa antavat kyseiselle haamualueelle.

Tämän tutkimuksen nuoret pitivät Karjalaa merkittävänä sekä Suomelle kansallisesti että itselleen henkilökohtaisesti, ja heidän mielestään oli mielenkiintoista puhua ja oppia aiheesta, josta ei kuullut puhuttavan paljon. Osallistujien joukossa oli myös nuoria, joille Karjala ei vaikuttanut olevan tärkeä aihe tai kysymys. Tutkimuksen yksi tärkeä tulos oli se, että osallistujat eivät pitäneet Karjalaa myyttisenä kadotettuna paratiisina, vaan nykypäivän alueena, johon he liittivät melko kielteisiä merkityksiä. Karjalan läsnäolo arjessa ilmeisen arkipäiväisten assosiaatioiden muodossa voitiin yhdistää käsityksiin sen menettämisestä ja palauttamisesta. Sana Karjala synnytti osallistujissa joitakin voimakkaampia assosiaatioita ja reaktioita liittyen menetettyyn alueeseen ja Suomen kuvitteellisen me-yhteisön kokemaan menetykseen.

Tutkimuksen tulokset ovat relevantteja laajemmassa kontekstissa. Osallistujat sisällyttivät itsensä usein osaksi "meitä" suomalaisia, mikä tuo nationalismin tutkimukseen uutta tietoa siitä, miten ja milloin nuoret muodostavat käsityksiä tiettyyn kansakuntaan kuulumisesta, vaikka kyseinen kysymys ei kuulunutkaan tämän tutkimuksen piiriin. Tutkimuksen tulokset vaikuttavat paikkaan kiinnittymiseen (place-attachment) liittyvään tutkimukseen alueen ja valtion tasolla. Tutkimuksessa tarkasteltiin sitä, miten nuoret ymmärtävät (heidän) kansan(sa) materiaalisen alueen "omistuksen" menettämisen ja suomalaisissa kansakunnan rakentamisen narratiiveissa yhä kulttuurisesti merkittävänä ja arvokkaana pidetyn alueen immateriaalisen menettämisen (Browning \& Joenniemi 2014; Laine \& van der Velde 2017). Tutkimukseen osallistuneet nuoret eivät ilmaisseet henkilökohtaisia luovutettuun Karjalaan kohdistuvia menetyksen tai kaipuun tunteita. Tämä viittaa siihen, että alueellisen haamukivun tunteminen ei ole väistämätön tai automaattinen reaktio kansallisen alueen menettämiseen. Se, että tutkimukseeni osallistuneet nuoret eivät pitäneet Karjalaa täydellisenä menetettynä paikkana, on yksi suurimmista eroista heidän ja evakkosukupolven kertomusten välillä. Tämän kaltaiset tutkimukset ovatkin merkityksellisiä siksi, että voidaan havaita, kuinka paikkoihin liitetyt merkitykset voivat muuttua ja kuinka alueeseen kiinnittymisen kokemukset voivat "vaipua unohduksiin" ajan myötä (Billé 2014, 180). 
Tämä tutkimus tuo uutta tietoa rajatutkimuksen kentälle, sillä tutkimuksessa tarkastellaan sekä alueellisen rajan pakotetun uudelleensijoittamisen vaikutuksia että menetetyn paikan merkitysten rajat ylittäviä mahdollisuuksia, eli voivatko merkitykset ylittää sukupolvien rajoja. Tutkimuksessa todetaan myös, että menetetyn Karjalan muisto jähmettyi, koska paikka rajattiin fyysisesti ja henkisesti täydelliseksi menetetyksi suomalaiseksi paikaksi. Tutkimalla tuntevatko suomalaiset nuoret menetetystä Karjalasta johtuvaa alueellista haamukipua, tämä artikkeli on käsitellyt yhtä rajatutkimuksen piirissä esitettyä kysymystä: Miksi monissa tapauksissa rajamuutokset aiheuttavat yhteiskunnassa voimakkaita tunnereaktioita, kun taas toisissa tapauksissa muuttuneet rajat nähdään perusteltuina? (Kolosov 2015, 40). Tämä artikkeli on vastannut kysymykseen osoittamalla, ettei nuorilla nykypäivän Suomessa ole voimakkaita tunnereaktioita rajamuutoksen myötä menetettyä Karjalaa kohtaan. Artikkeli väittää tämän johtuvan siitä, että kyseessä on tilallisen sosialisaation prosessien kautta opittu tunnereaktio, jota nuoret eivät (tähän mennessä) ole sisäistäneet. Samankaltaiset tutkimukset, jotka nuoria osallistamalla tarjoavat näkymiä alhaalta päin, voivat "rikastuttaa ymmärrystämme rajoista ja raja-alueista sosiaalisina konstruktioina ja ihmisten arkielämän käytänteiden tuloksena" (Spyrou \& Christou 2014, 3). Tämä tutkimus on tuonut esiin, miten nuoret Suomessa ymmärtävät Karjalan, joka on "välitila... määrittämätön mutta hyvin symbolinen alue" (Laine \& van der Velde 2017, 67), ja miten nuoret aktiivisesti (re)konstruoivat sitä.

Tutkimuksen tuloksissa korostuvat nuorten "monimutkaiset, ristiriitaiset ja sekavat vastaukset", kun he neuvottelevat kiisteltyyn alueeseen liittyvistä merkityksistä (McKnight \& Leonard 2014, 177). Nämä merkitykset siirtyvät heihin tilallisen sosialisaation prosessien kautta ja he ilmaisevat niitä (uudelleen) "toisiinsa sidoksissa olevina, mutta ainutlaatuisina yksilöinä” (Kallio 2014, 215), joilla on valtaa muokata ja luoda uudelleen vakiintuneita merkityksiä. Tämä tutkimus osoittaa, että on tarpeen sisällyttää nuorten näkemyksiä laajempaan keskusteluun raja-alueista ja rajojen sosiaalisesta rakentumisesta sekä alueiden kansallisista merkityksistä.

Tutkimus on luonut tilannekuvan niistä käsityksistä, joita suomalaisilla nuorilla on Karjalasta tietyllä hetkellä heidän elämässään ja heidän kansansa historiassa. Kuten oikeissakin tilannekuvissa, asiat kuitenkin jatkavat liikkumista ja muuttumista välittömästi kuvan ottamisen jälkeen. Olisikin mielenkiintoista nähdä pitkän aikavälin tutkimus niistä merkityksistä, joita kolmas sukupolvi liittää Karjalaan ja siitä, muuttuvatko nämä merkitykset heidän elämänsä aikana ja jos muuttuvat, miten. Jatkotutkimuksessa aihetta voitaisiin käsitellä pitkittäistutkimuksen keinoin palaamalla saman kohortin (tai mahdollisuuksien mukaan jopa samojen osallistujien) luokse myöhemmin ja arvioimalla, ovatko heidän Karjalaan liittämänsä merkitykset muuttuneet. Tällä tavoin voitaisiin selvittää, vaikuttiko osallistujien elämänvaihe tämän tutkimukssen tuloksiin (esimerkiksi se, että he olivat lukiolaisia eli nuoria, joilla ei ollut vielä ollut kovin paljon mahdollisuuksia kartuttaa tietojaan tai kehittyä ja/tai kiinnostua aiheesta) vai säilyvätkö kolmannen sukupolven Karjalaan liittämät merkitykset muuttumattomina läpi heidän elämänsä. 


\section{Viitteet}

1 Kaupungit olivat: Helsinki, Imatra, Joensuu, Jyväskylä, Lahti, Lappeenranta, Oulu, Rovaniemi, Turku, Vaasa ja Vantaa. Ryhmien koko vaihteli 3-14 osallistujan välillä. Keskimääräinen ryhmäkoko oli 8,5 osallistujaa per ryhmä. Ryhmähaastattelut kestivät yleensä noin tunnin.

2 Fokusryhmähaastattelun lainausten yhteydessä ilmoitetaan osallistujan $(\mathrm{O})$ puhujanumero ja sukupuoli ( $\mathrm{M}=$ mies, $\mathrm{N}=$ nainen), kuten myös ryhmän sijainti ja ryhmän numero. Tässä esimerkissä naisosallistuja (NO) oli ensimmäinen puhuja ryhmässään (Joensuun ryhmä 1), ja on siten merkitty puhujanumerolla 1. Lainattaessa fokusryhmähaastattelun katkelmaa, jossa vain puhujan sukupuoli on tiedossa, eli toisin sanoen puhuja on tunnistamaton, määrite on "NO" tai "MO".

3 Tämä viittaa nimettömään palautelomakkeeseen, joka täytettiin ryhmähaastattelun päätteeksi. Tässä on kyseessä palautelomake (P) numero 4 Vaasan ryhmästä 4.

4 Tämä viittaa nimettömiin kirjallisiin yhteenvetoihin, joita osallistujat kirjoittivat ryhmähaastattelun päätteeksi. Tässä on kyseessä yhteenveto numero 2 Helsingin ryhmästä 1 .

5 Luovutetulla Karjalan alueella. Toisesta maailmansodasta lähtien Primorsk, Leningradin alue, Venäjä.

\section{Lähteet}

\section{Haastattelut:}

Fokusryhmähaastatteluiden transkriptiot

Osallistujien fokusryhmähaastattelun päätteeksi kirjoittamat yhteenvedot

Osallistujien fokusryhmähaastattelun päätteeksi kirjoittamat palautelomakkeet

\section{Kirjallisuus:}

Ahponen, Pirkkoliisa (2011), Miserable or Golden Karelia? Interpreting a Cross-Border Excursion of Students from Finland to Russia. - Journal of Borderlands Studies 26: 2, 145-159.

Armstrong, Karen (2004), Remembering Karelia: A Family's Story of Displacement During and After the Finnish Wars. Oxford: Berghahn.

Billé, Franck (2014), Territorial Phantom Pains (and Other Cartographic Anxieties). - Environment and Planning D: Society and Space, 32: 1, 163-178.

Billé, Franck (2016), Introduction to 'Cartographic Anxieties.' - Cross-Currents: East Asian History and Culture Review 21, 1-18.

Billig, Michael (1995), Banal Nationalism. London: Sage.

Braun, Virginia. \& Clarke, Victoria. (2006), Using Thematic Analysis in Psychology. - Qualitative Research in Psychology 3:2, 77-101.

Browning, Christopher S, \& Joenniemi Pertti (2014), Karelia as a Finnish-Russian Issue: Re-Negotiating the Relationship between National Identity, Territory and Sovereignty. - CEURUS EU-Russia Paper 18.

Böök, Netta (2004), Border Karelia through Rose-Coloured Glasses? Gazes upon a Ceded Territory. - Fennia 182: 1 SPEC. ISS., 33-45.

Cameron, Jennifer (2005), Focusing on the Focus Group. - Qualitative Research Methods in Human Geography, 2nd edition. Toim. Iain Hay. Oxford: Oxford University Press, 156-174.

Fingerroos, Outi (2008), Karelia: A Place of Memories and Utopias - Oral Tradition 23:2, 235-254. 
Habashi, Janette (2013), Palestinian Children : Authors of Collective Memory - Children \& Society $27,421-33$.

Jukarainen, Pirjo (2003), Definitely Not Yet the End of Nations: Northern Borderlands Youth in Defence of National Identities. - Young Nordic Journal of Youth Research 11:3, 217-234.

Kaisto, Virpi \& Brednikova, Olga (2019), Lakes, Presidents and Shopping on Mental Maps: Children's Perceptions of the Finnish - Russian Border and the Borderland. - Fennia 197:1, 58-76.

Kallio, Kirsi-Pauliina (2014), Rethinking Spatial socialization as a Dynamic and Relational Process of Political Becoming. - Global Studies of Childhood 4:3, 210-223.

Karjalan Liitto (2019), Karjalan Liiton historia. Karjalan Liitto ry. https://www.karjalanliitto.fi/ karjalan-liitto/karjalan-liiton-historia.html (Tarkistettu 29.4.2019.)

Katajala, Kimmo \& Liikanen, Ilkka (2018), The Politics of History of the Lost Land: Shifting European, National and Regional Approaches to the History of Karelia. - How to Address the Loss? Forced Migrations, Lost Territories and the Politics of History: A Comparative Approach in Europe and at Its Margins in the XXth Century. Toim. Anne Bazin \& Catherine Perron. Brussels: Peter Lang.

Kolosov, Vladimir (2015), Theoretical Approaches in the Study of Borders. - Introduction to Border Studies Eds. Sergei V. Sevastianov, Jussi P. Laine \& Anton A. Kireev. Vladivostock: Far Eastern Federal University Press.

Kuusisto-Arponen, Anna-Kaisa (2003), Our Places - Their Spaces. Urban Territoriality in the Northern Irish Conflict. Väitöskirja. Tampereen yliopisto.

Laine, Jussi \& van der Velde, Martin (2017), Spiritually Ours, Factually Yours: Karelia and Russia in Finnish Public Consciousness. - Europa Regional 24, 65-79.

Liikanen, Ilkka (2014), Territoriality, State, and Nationality in the Making of Borders of Finland: The Evolving Concept of Border in the Peace Treaties between Russia and Sweden, 1323-1809. -Russian Sociological Review 13: 4, 105-115.

McKnight, Martina and Leonard, Madeleine (2014), Young People's Experiences in 'Post- Conflict' Belfast. - Children and Borders Toim. Spyros Spyrou \& Miranda Christou. Basingstoke: Palgrave Macmillan 164- 179.

Niukko, Kirsi (2009), The Concept of Landscape Among Karelian Migrants in Finland. - Journal of Borderlands Studies 24:2, 62-77.

Paasi, Anssi (1996), Territories, Boundaries and Consciousness: The Changing Geographies of the Finnish-Russian Border. Chichester: John Wiley.

Paasi, Anssi (2016), Dancing on the Graves: Independence, Hot/Banal Nationalism and the Mobilization of Memory - Political Geography 54, 21-31.

Savolainen, Ulla (2017), The Return: Intertextuality of the Reminiscing of Karelian Evacuees in Finland. - Journal of American Folklore 130: 516, 166-192.

Scourfield Jonathan, Dicks, Bella, Drakeford, Mark \& Davies, Andrew (2006), Children, Place and Identity: Nation and Locality in Middle Childhood. Abingdon: Routledge.

Spyrou, Spyros \& Miranda. Christou (2014), Introduction. - Children and Borders Toim. Spyros Spyrou \& Miranda Christou. Basingstoke: Palgrave Macmillan, 1-23.

Wells, Chloe (2016), Eating Karelia: the Geography, History, and Memory of Karelian Pies. - Carelica 2016:2, 72-82.

Wolnik, Kevin, Busse, Britta, Tholen, Jochen, Carsten, Yndigegn., Levinsen, Klaus, Saari, Kari, \& Puuronen, V. (2016), The Long Shadows of the Difficult Past? How Young People in Denmark, Finland and Germany Remember WWII. - Journal of Youth Studies 20:2, 162-79.

\section{Muu media - laulut:}

JVG feat. Freeman (2012) Karjala takaisin. Monsp Records Oy.

Portion Boys (2017) Karjala takas. Saumaa Records. 